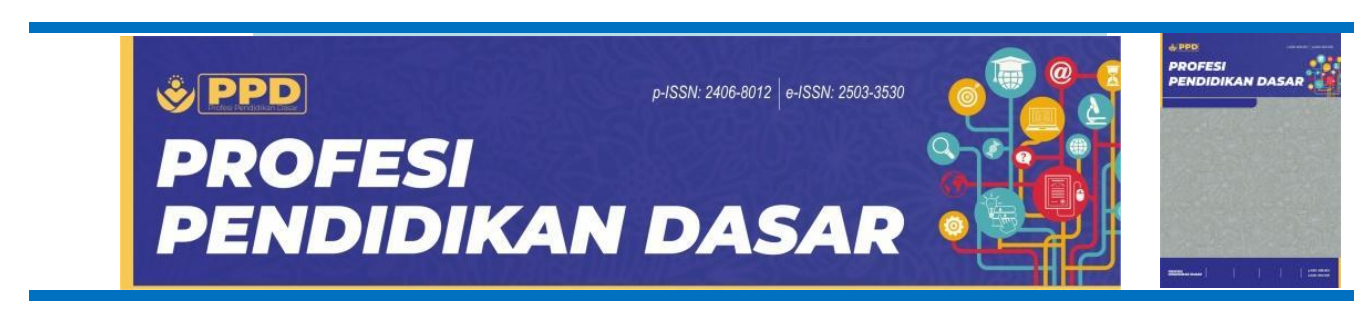

\title{
STEAM Oriented Science Learning Management During The COVID-19 Pandemic
}

\author{
Mimin Vera Dwi Priyantini", Bambang Sumardjoko, Choiriyah Widyasari, Yulia \\ Maftuhah Hidayati \\ Universitas Muhammadiyah Surakarta, Surakarta, Indonesia \\ *Email: q200200004@student.ums.ac.id
}

Submitted: 2021-07-12

DOI: $10.23917 / p p d . v 8 i 2.15155$

Accepted: 2021-12-16

Published: 2021-12-27

\begin{tabular}{ll}
\hline \multicolumn{1}{c}{ Keywords: } & Abstract \\
\hline pandemic; & This research was motivated by the importance of experimentation in science \\
& learning which cannot be done directly in online learning during the pandemic. \\
steam; & The application of STEAM is one solution to problems that arise in the \\
management of science learning in elementary schools during the pandemic. & The subjects of this study were 20 grade 6 students in an elementary school in \\
science learning; & Surakarta. The method used in this study was descriptive qualitative with a case \\
management; & study design. The recruited informants consisted of students and their parents. \\
tolerance & The techniques used in this research are interviews, observation and \\
assessment; & $\begin{array}{l}\text { documentation. Data analysis using data collection techniques, data reduction, } \\
\text { presentation of power and drawing conclusions. The data validity technique is } \\
\text { technique triangulation and source triangulation. The results of this study } \\
\text { indicate that (1) the application of online learning changes the way students } \\
\text { learn (2) In online learning experiments cannot be done directly (3) During the } \\
\text { pandemic, teachers are required to innovate in the teaching and learning } \\
\text { process (4) The STEAM approach can provide a meaningful experience for } \\
\text { students (5) STEAM can encourage student development for the better. The } \\
\text { implications of this research are: First, more and more teachers are } \\
\text { implementing the STEAM approach in the teaching and learning process as an } \\
\text { alternative so that students can learn optimally. Both parents are willing to take } \\
\text { the time to observe and assist their daughter's online learning process. This } \\
\text { studydescribes the application of the STEAM approach in online learning during } \\
\text { a pandemic. }\end{array}$
\end{tabular}

(C) The Author(s). 2021

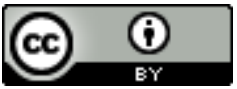

This work is licensed under a Creative Commons Attribution 4.0 International License 


\section{INTRODUCTION}

\section{Background}

In 2020, the outbreak of Coronavirus Disease-2019 (covid 19) has not shown any signs of slowing down. Recently, a new variant of the COVID-19 virus was discovered, namely the delta variant. This new variant of the virus has killed hundreds of thousands of people around the world. On Wednesday, July 14, 2021, at 07.00 WIB, Worldometer reported that there were $188,563,150$ cases of Covid 19 worldwide. A total of 4,065,129 people were declared dead and 172,396,201 people were declared cured(Muhamad, 2021). The skyrocketing spread of COVID-19 cases has prompted the government to immediately take action to contain the spread of the COVID-19 virus, one of which is the determination of a joint decision (SKB) of 4 ministers regarding the Guidelines for the Implementation of Learning in the Covid-19 Pandemic Period (Kemdikbud RI, 2020). In the joint decision, it is explained that the implementation of learning in 2021/2022 must pay attention to the respective regional zones. For Surakarta, entering the 2021/2022 school year, it is stated that it is still at level 4 , the implementation of the teaching and learning process is carried out online, such as the implementation of learning in the $2020 / 2021$ school year.

June 12, 2021 is the first day of school in the year 2021/2022. According to the instructions in the SKB 4 ministers in 2021, the learning activities that take place are still using the online system considering the risk of the spread of the COVID-19 virus is still very high. Learning is carried out synchronously or asynchronously. In Indonesia, synchronous learning still relies on the use of proprietary video teleconferencing software program (Busa et al., 2020). For asynchronous WhatsApp groups are still a mainstay for most teachers and parents (Daheri et al., 2020). A small number have also used the Microsoft 365 application or Google Class because of the limited abilities and facilities owned by students. Students are prohibited from coming to school and must study independently from home. This is a new phenomenon that poses new challenges in the world of education. If under normal conditions the world of education is filled with face-to-face activities between students and teachers, this cannot be done during this pandemic. Learning and teaching activities are filled with virtual face-to-face activities. Teachers and students meet in cyberspace.

During this pandemic, teachers are required to designing media for teaching and learning activities that encourage innovative and creative power so that students can continue to receive maximum learning. All efforts made by all parties for the implementation of online learning have the aim of providing learning facilities so that students can learn meaningfully that is not bound by space and time during the pandemic (Handayani et al., 2020; Kurniasari, 2020; Shah, 2020)(Suswandari et al., 2021). It is a challenge for elementary school teachers with limited facilities owned by students considering that the majority of elementary school age children do not have their own gadgets / cellphones and rely on their parents' cellphones. Electronic equipment facilities (HP, laptops, etc.) are the main factors in the online PJJ process, this will facilitate the delivery of material to students for the smooth teaching and learning process (Purwanto et al, 2020: 7)(Bahri \& Budiyono, 2020). So that teachers are required to hold a learning process that can touch the whole of their students. Especially for logic subjects such as mathematics and science.

Science learning would be better to apply experimental methods that can develop the competence of students. Good science learning encourages students to get used to using scientific methods or process skills in studying science (Suriasumantri in Patta Bundu, 2006: 3). Because the implementation of science learning based on the 2013 curriculum should apply a scientific approach. In accordance with the Minister of Education and Culture 
Regulation Number 81A of 2013 regarding the implementation of the 2013 curriculum in Appendix IV, it is explained that the approach that is in accordance with the 2013 curriculum is a scientific approach in collaboration with a problem-based and project-based approach. Good science content should encourage students to develop 4C Skills (critical thinking, creative, communication,(Khaira, 2018). Koballa and Chiapetta (2010: 105) define science as a science that demands investigation in obtaining new knowledge, and interaction with technological sophistication and society. It can be interpreted that in Natural Sciences has the dimension of thinking patterns, demanding investigation and building science and its relationship with technological sophistication and society.(Peserta \& Smp, 2016).

\section{Problem of Study}

Science learning activities should be able to improve the competence of students by providing meaningful experiences for students, one of which is by conducting direct experiments. However, at this time science learning cannot be carried out optimally because we are in the time of the covid 19 pandemic. This requires the teaching and learning process to be carried out online from home. This is in line with the Circular of the Minister of Education and Culture no. 35492/A.A5/HK/2020 which was set on March 2, 2020 related to stemming the spread of Covid-19 transmission. Online learning must remain meaningful for students. Science learning should facilitate students to gain meaningful personal experiences for students, therefore students do not only understand theory, but an even greater hope is that students can apply newly acquired insights to find solutions to real-life problems. However, due to conditions that do not support conventional learning, these expectations cannot be realized optimally. This phenomenon is also faced by students at SDN Kepatihan in learning Natural Sciences (IPA) with the sub-material of simple electrical circuits. If under normal conditions this material is in great demand by students because they will be invited to experiment directly with friends in class with the guidance of the teacher and if they face difficulties will immediately get help from the teacher and friends. However, during the pandemic, all of these activities cannot be carried out because the teaching and learning process is carried out online. Teachers are required to design innovative teaching and learning processes in dealing with these conditions.

Current conditions encourage teachers to be smart in looking for techniques so that students can still learn meaningfully but still carry out recommendations from the government to continue to carry out the teaching and learning process with an online system. Therefore, the application of STEAM in the teaching and learning process is seen as a way that is able to overcome these problems. The STEAM approach is a way that can be a solution to answer the challenges of education during a pandemic with various limitations of current conditions. Irmani.L, et al.(2019) explained that STEAM is an approach in learning that can stimulate curiosity and be able to increase the curiosity of students so that they have skills in finding solutions in dealing with problems, cooperation, individual learning by applying a project-based learning process, research-based learning process and challenges. Henceforth, the selection and implementation of a STEAM-based curriculum (Science, Technology, Engineering, Art, and Math) has a very important role in increasing the creative ability of students which focuses on cooperation, creativity, developing communication skills both verbal and non-verbal research. , problem solving and critical thinking. With the STEAM approach, it is expected that students have good intelligence in academic aspects but are also intelligent in social and emotional aspects and Math has a very important role for increasing the creative ability of students which focuses on cooperation, creativity, developing communication skills both verbal and non-verbal research, problem solving and critical thinking. With the STEAM approach, it is expected that students have good intelligence in academic aspects but are also intelligent in social and emotional aspects and 
Math has a very important role for increasing the creative ability of students which focuses on cooperation, creativity, developing communication skills both verbal and non-verbal research, problem solving and critical thinking. With the STEAM approach, it is expected that students have good intelligence in academic aspects but are also intelligent in social and emotional aspects (Kumar, 2016).

\section{State of the Art}

Some researchers who have researched the application of STEAM one of them are(Billiark et al., 2014)describes STEAM as a space that invites, encourages, and provides a safe learning environment where students have more freedom to explore and gain a deeper understanding of the arts and other disciplines. STEAM is also able to encourage good children's growth and development so that they grow into children who develop according to the demands of development according to their phases(Daugherty et al., 2014). The application of STEAM in learning is able to encourage the growth of creativity, critical thinking and can help gain a strong understanding of the material(Farwati et al., 2017). In early childhood the STEAM approach also significantly shapes students into children who have skills in problem solving and are able to socialize with the surrounding environment and are able to come up with creative ideas based on science and technology.(Melati et al., 2019), (Nurhikmayati, 2019) and (Susanti et al., 2020). The application of STEAM is able to develop genius talents in students and encourage students to think critically and have good scientific literacy skills(Adriyawati et al., 2020).(Kim \& Park, 2012) The use of the STEAM approach in the teaching and learning process helps students to analyze the problems they are facing by involving 5 disciplines including science, technology, engineering, art and mathematics so that it will create strong resilience in the face of globalization. (Iolanessa et al., 2020)(Purnamasari et al., 2020). In addition to the advantages of the STEAM approach that have been described by several researchers above, the STEAM approach indicates that the application of STEAM has not been fully integrated in the teaching and learning process so far, so it requires assistance from experts and has not utilized comprehensive learning media.(Munawar et al., 2019).

\section{Gap Study \& Objective}

Based on the background described above, this study aims to describe the management of the application of STEAM in the subject matter of Natural Sciences (IPA) in grade 6 SDN Kepatihan for the academic year 2020/2021 with the material "Simple Electrical Circuits". The contribution of this research is that more and more fellow teachers are implementing this STEAM approach in learning so that students learn more meaningfully and learning objectives can be achieved. In previous studies, the application of STEAM was not carried out by online learning and was carried out face-to-face in the classroom. In this study, the application of STEAM was carried out during the pandemic and by implementing online learning as recommended by the government.

\section{METHOD}

\section{Type and Design}

The method applied in this research is descriptive qualitative with a case study research design, an inductive research perspective, which is centered on exploring and understanding individual meanings and translating the complexity of a problem (Creswell, 2010:5). The research will draw/photograph the application of the STEAM approach by observing each stage of STEAM implementation in science subjects with the material "Simple electrical circuit". Cresswel (2012) explains that this research can examine the status of a group of people related to objects, conditions or events that are happening right now (Yanuarto, 2018: 15). 
The subjects in this study were grade 6 students for the 2020/2021 academic year, totaling 20 students. This class was chosen as the research subject because this class as a whole has facilities in the form of gadgets for the application of STEAM in online learning. The data taken is not only taken from students but also involves parents because parents who directly accompany the learning process during the online system are implemented.

Table 1. Indicators of Learning Management by Implementing STEAM

\begin{tabular}{|c|c|c|c|}
\hline Stage & Teacher's Role & $\begin{array}{c}\text { Role } \\
\text { Learners }\end{array}$ & Method \\
\hline Exploration & $\begin{array}{l}\text { Provide opportunities for } \\
\text { students to explore } \\
\text { interesting things from the } \\
\text { material "Simple Electrical } \\
\text { Circuits" }\end{array}$ & $\begin{array}{l}\text { Actively submit } \\
\text { proposals/opinions on } \\
\text { activities or materials to } \\
\text { be studied related to the } \\
\text { material "Simple } \\
\text { Electrical Circuits" }\end{array}$ & $\begin{array}{l}\text { Discussion } \\
\text { by using } \\
\text { zoom } \\
\text { meeting }\end{array}$ \\
\hline $\begin{array}{l}\text { Generating } \\
\text { new ideas } \\
\text { (New Idea) }\end{array}$ & $\begin{array}{l}\text { Offer a learning design to } \\
\text { accommodate all suggestions } \\
\text { and opinions from the } \\
\text { exploration stage }\end{array}$ & $\begin{array}{l}\text { Students provide } \\
\text { suggestions from the } \\
\text { learning design proposed } \\
\text { by the teacher so that the } \\
\text { design is more interesting } \\
\text { and meaningful }\end{array}$ & $\begin{array}{l}\text { Discussion } \\
\text { by using } \\
\text { zoom } \\
\text { meeting }\end{array}$ \\
\hline $\begin{array}{l}\text { Creating and } \\
\text { developing } \\
\text { models } \\
\text { (Innonation) }\end{array}$ & $\begin{array}{l}\text { The teacher encourages } \\
\text { students to explain what } \\
\text { things must be done to the } \\
\text { agreed design. }\end{array}$ & $\begin{array}{l}\text { Students actively } \\
\text { describe the things that } \\
\text { will be done against the } \\
\text { agreed design }\end{array}$ & $\begin{array}{l}\text { Discussion } \\
\text { by using } \\
\text { zoom } \\
\text { meeting }\end{array}$ \\
\hline $\begin{array}{l}\text { Steps of } \\
\text { creation } \\
\text { (Creativity) }\end{array}$ & $\begin{array}{l}\text { The teacher gives } \\
\text { instructions for students to } \\
\text { design simple circuits } \\
\text { (parallel and series) }\end{array}$ & $\begin{array}{l}\text { Students design simple } \\
\text { circuits (parallel and } \\
\text { series) }\end{array}$ & $\begin{array}{l}\text { Independe } \\
\text { ntly } \\
\text { working in } \\
\text { their } \\
\text { respective } \\
\text { homes. }\end{array}$ \\
\hline $\begin{array}{l}\text { Drafting } \\
\text { plans }\end{array}$ & $\begin{array}{l}\text { The teacher provides } \\
\text { instructions and } \\
\text { opportunities for students to } \\
\text { prepare the planned design }\end{array}$ & $\begin{array}{l}\text { Students design simple } \\
\text { electrical circuits }\end{array}$ & $\begin{array}{l}\text { Independe } \\
\text { ntly done } \\
\text { in their } \\
\text { respective } \\
\text { homes and } \\
\text { discussed } \\
\text { in the wa } \\
\text { group }\end{array}$ \\
\hline $\begin{array}{l}\text { Communicati } \\
\text { on and } \\
\text { reflection } \\
\text { (communicat } \\
\text { ion and } \\
\text { reflection) }\end{array}$ & $\begin{array}{l}\text { The teacher asks students to } \\
\text { communicate/present their } \\
\text { work and provide input from } \\
\text { the student's presentation. }\end{array}$ & $\begin{array}{l}\text { Students present their } \\
\text { work. }\end{array}$ & $\begin{array}{l}\text { Presentati } \\
\text { on using } \\
\text { zoom } \\
\text { meeting }\end{array}$ \\
\hline
\end{tabular}




\section{Data and Data Sources}

The data in this study were obtained from interviews with students and interviews with parents of grade 6 students at SDN Kepatihan in 2021 and data obtained by researchers from observations and documentation during the research process. Data collection techniques used in this study were interviews and documentation.

\section{Data collection technique}

\section{Observation}

The observations used in this study were non-participatory observations. Researchers asked parents for help to make observations because conditions did not allow researchers to make direct observations of students.

The aspects observed from the informants (students) are as follows: (1) Observing the preparation phase (2) Observing the implementation of STEAM-oriented learning (3) Observing the stage of making electrical circuit designs in STEAM-oriented online learning

\section{Interview}

Data collection techniques through interviews were carried out to explore information related to the development of students during online learning. This interview was conducted by utilizing video call media as a means of conducting interviews. Interviews conducted with students were used to obtain information related to the application of STEAM in online learning. Interviews conducted with parents of students were used to obtain information about the support and obstacles faced during the implementation of STEAM in online learning. Documentation is used to capture every stage of the implementation of STEAM in online learning with the material "Simple electrical circuits".

The grid of interviews with students conducted by researchers is as follows:

Table 2. Interview Grid With Students

\begin{tabular}{|c|c|c|c|}
\hline Aspect & Research Questions & Indicator & Informant \\
\hline \multirow{2}{*}{$\begin{array}{l}\text { Implementation of PJJ in } \\
\text { the science learning } \\
\text { process from the point of } \\
\text { view of students }\end{array}$} & $\begin{array}{l}\text { What do you think about } \\
\text { the implementation of } \\
\text { online learning? }\end{array}$ & $\begin{array}{l}\text { Opinion, } \\
\text { experience }\end{array}$ & Learners \\
\hline & $\begin{array}{l}\text { Which is more } \\
\text { comfortable for you to } \\
\text { study face to face or } \\
\text { online? Why? }\end{array}$ & & \\
\hline $\begin{array}{l}\text { Application of STEAM in the } \\
\text { online learning process }\end{array}$ & $\begin{array}{l}\text { What tools have you } \\
\text { prepared in participating } \\
\text { in the online learning } \\
\text { process? }\end{array}$ & & \\
\hline & $\begin{array}{l}\text { Are you able to operate all } \\
\text { the applications found on } \\
\text { the gadget? } \\
\text { What applications are } \\
\text { often used in online } \\
\text { learning? }\end{array}$ & & \\
\hline $\begin{array}{l}\text { Inhibiting factors in the } \\
\text { application of STEAM in } \\
\text { online learning }\end{array}$ & $\begin{array}{l}\text { Is the network at your } \\
\text { place smooth or does it }\end{array}$ & & \\
\hline
\end{tabular}


Priyantini et al - STEAM Oriented Science Learning Management...

\begin{tabular}{|c|c|c|c|}
\hline Aspect & Research Questions & Indicator & Informant \\
\hline & $\begin{array}{l}\text { often experience } \\
\text { problems? } \\
\text { What problems have you } \\
\text { experienced in the online } \\
\text { learning process? }\end{array}$ & & \\
\hline $\begin{array}{l}\text { Supporting factors in } \\
\text { implementing STEAM in } \\
\text { online learning }\end{array}$ & $\begin{array}{l}\text { Do you have your own } \\
\text { HP? }\end{array}$ & & \\
\hline $\begin{array}{l}\text { Suggestions from students } \\
\text { for implementing STEAM in } \\
\text { online learning }\end{array}$ & $\begin{array}{l}\text { What do you find } \\
\text { interesting online learning } \\
\text { during this pandemic? }\end{array}$ & & \\
\hline
\end{tabular}

The lattice of interviews with parents of students conducted by researchers are as follows:

Table 3. Interviews with parents of students

\begin{tabular}{|c|c|c|c|}
\hline Aspect & Research Questions & Indicator & $\begin{array}{c}\text { Informa } \\
\text { nt }\end{array}$ \\
\hline \multirow{2}{*}{$\begin{array}{l}\text { Implementation of } \\
\text { online learning in the } \\
\text { science learning } \\
\text { process from the point } \\
\text { of view of students }\end{array}$} & $\begin{array}{l}\text { What do you think about the } \\
\text { implementation of online } \\
\text { learning? }\end{array}$ & $\begin{array}{l}\text { Opinion, } \\
\text { experience }\end{array}$ & $\begin{array}{l}\text { student } \\
\text { Guardia } \\
\mathrm{n}\end{array}$ \\
\hline & $\begin{array}{l}\text { In your opinion, which one is } \\
\text { more effective, online or face-to- } \\
\text { face learning? }\end{array}$ & & \\
\hline \multirow[t]{3}{*}{$\begin{array}{l}\text { Application of STEAM } \\
\text { in the online learning } \\
\text { process }\end{array}$} & $\begin{array}{l}\text { What tools have you prepared } \\
\text { for your son/daughter to take } \\
\text { part in the online learning } \\
\text { process? }\end{array}$ & & \\
\hline & $\begin{array}{l}\text { Do you know what applications } \\
\text { have been installed on your } \\
\text { son/daughter's cellphone? }\end{array}$ & & \\
\hline & $\begin{array}{l}\text { According to your observations, } \\
\text { does the application of STEAM } \\
\text { have a positive impact on the } \\
\text { development of your } \\
\text { son/daughter? }\end{array}$ & & \\
\hline \multirow{2}{*}{$\begin{array}{l}\text { Inhibiting factors in } \\
\text { the application of } \\
\text { STEAM in online } \\
\text { learning }\end{array}$} & $\begin{array}{l}\text { Is the network at your place } \\
\text { smooth or does it often } \\
\text { experience problems? }\end{array}$ & & \\
\hline & $\begin{array}{l}\text { How much internet quota } \\
\text { capacity do you provide each } \\
\text { week for your son/daughter? }\end{array}$ & & \\
\hline $\begin{array}{l}\text { Supporting factors in } \\
\text { implementing STEAM } \\
\text { in online learning }\end{array}$ & $\begin{array}{l}\text { Do you always accompany your } \\
\text { son/daughter in online learning? }\end{array}$ & & \\
\hline
\end{tabular}




\begin{tabular}{lll}
\hline \multicolumn{1}{c}{ Aspect } & \multicolumn{1}{c}{ Research Questions } & $\begin{array}{l}\text { Indicator } \\
\text { Informa } \\
\text { nt }\end{array}$ \\
\hline $\begin{array}{l}\text { Suggestions from } \\
\text { parents for }\end{array}$ & $\begin{array}{l}\text { In your opinion, what are the } \\
\text { interesting things about online }\end{array}$ & \\
$\begin{array}{l}\text { implementing STEAM } \\
\text { in online learning }\end{array}$ & learning during this pandemic? & \\
$\begin{array}{l}\text { Suggestions from } \\
\text { students for the } \\
\text { application of STEAM } \\
\text { in online learning }\end{array}$ & $\begin{array}{l}\text { In your opinion, what are the } \\
\text { interesting things about online }\end{array}$ & \\
\hline
\end{tabular}

Data Validity

Test the validity of the data used in this study is to use triangulation of sources. The interviewees in this study were students and parents of participants. In addition, the data will be strengthened by the implementation of documentation during the process of implementing STEAM in online learning. Triangulation has the meaning of comparing and re-checking the level of trust in data generated through different times and tools (Patton 1987:331) as well as peer-checking through discussion to enrich information.

\section{Data Analysis}

The data analysis technique used in this study is a qualitative research data analysis technique with the type of Flow model (flow). In the flow data analysis technique, there are two main phases, namely the data collection phase and the post phase(Miles, 1994). At the data collection stage, researchers can directly reduce data, display data, group data from data obtained from interviews and documentation and then make initial conclusions from the research conducted. After that stage, the researcher wrote the results of his research on the management of STEAM-oriented learning in grade 6 SDN Kepatihan.

\section{RESULT}

\section{The Results of The Observation of The Preparation Stage}

At this stage, there are several components that need to be prepared, namely: (1) the teacher sends a summary of the material in the form of a printout containing a summary of the material that has been prepared and distributed to parents when the schedule for collecting assignments is as usual. (2) the teacher shares a youtube link containing the material "simple electrical circuits, (3) the teacher sends a zoom meeting link for the implementation of STEM-oriented learning, (4) the teacher shares a google form link as a means of observation that must be filled in by parents (5) Stage Next, the teacher sends a quizz link which contains 15 questions that students have to do

The Results of Observations of The Implementation of STEAM-Oriented Learning The implementation of STEAM-oriented science learning is divided into several stages, namely:

(1) The implementation of science learning activities in grade 6 at SDN Kepatihan as long as STEAM is implemented is a student activity schedule made by the teacher once a week. The schedule explains in detail what will be done, as well as the activities that will be done by students for one week. The learning resources used are student thematic books borrowed from schools. In addition, in addition, the teacher makes a summary of the material that will be duplicated by as many as students. According to the agreement, every Monday the student's guardian will come to school to pick up the schedule of activities and additional materials that have been prepared. In 
addition to taking the schedule, this opportunity is used to collect the results of student work for one week in the form of a spreadsheet.

\begin{tabular}{|c|c|c|c|c|}
\hline & & & DWAL PJJ ( PEMBELAJARAN JARAK JAUH) K & \\
\hline & & & SD N KEPATIHAN & \\
\hline & & & TAHUN AJARAN $2020 \nmid 2021$ & \\
\hline TANG: & AL, 24-28 AG & ISTUS 2020 & & \\
\hline TEMA & & : SELAMATK & MAHKLUK HIDUP & \\
\hline SUB T & MA 3 & : AYO SELAR & KAN HEWAN DAN TUMBUHAN & \\
\hline SENIN & 4 Agustus 20 & 0 LIBUR PERI & TAN HARI KEMERDEKAAN & \\
\hline NO & WAKTU & MUPEL & KEGIATAN & TAGIHAN \\
\hline 1 & $07.30-07.30$ & Olah Riaga & Olah raga Ringan & - \\
\hline 2 & $07.30-08.00$ & Pembiasaan & mandi Pagi dan Sarapan & \\
\hline 3 & $08.00-09.30$ & IPA & Mengerjakan LKS Tema $1 \mathrm{Hal}$ 68-70 & Kertas Folio \\
\hline 4 & $09.30-10.00$ & Pembiasaan & Istirahat dan Sholat Dhuha & \\
\hline 5 & $10.00-11.00$ & IPS & Penilaian Harian "Materi ASEAN" & Google Form \\
\hline 6 & $11.00-12.00$ & SBdP & Membuat patung dengan bahan dasar Sabun batang & $\begin{array}{l}\text { Hasil dikumpulkan satu } \\
\text { minggu setelahnya }\end{array}$ \\
\hline SELAS & 25 AGUSTL & 52020 & & \\
\hline NO & WAKTU & MUPEL & KEGIATAN & TAGIHAN \\
\hline 1 & $07.00-07.30$ & Pembiasaan & Senam Pagi & - \\
\hline 2 & $07.30-08.00$ & Pembiasaan & mandi Pagi dan Sarapan & \\
\hline
\end{tabular}

Figure 1: Example of class 6 PJJ schedule

(2) This research begins with conducting interviews on the implementation of distance learning (PJJ) which has been carried out by utilizing the google form application.

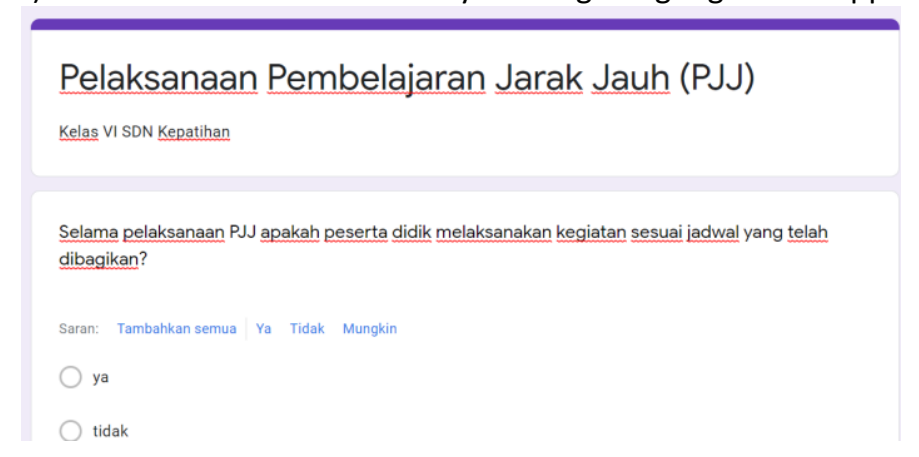

Figure 2: Observation using google form

(3) The next stage carried out by the researchers was to apply the STEAM approach in teaching and learning activities. This activity begins by dividing students into groups because most students still use their parents' cellphones, which in the morning they have to work and it is not possible to take part in online activities in the morning. So the researcher grouped the students into 2 groups, namely the group in the morning and the group at night. The morning group is students who in the morning do not have problems participating in online activities in the morning. The night group is students who experience problems if they have to take part in online activities in the morning because students don't always carry cellphones.

(4) Make an agreement with parents that online learning activities in the morning start at $08.00-09.30$ WIB and the afternoon group starts at $18.30-20.00$ WIB by using the zoom meeting application. 


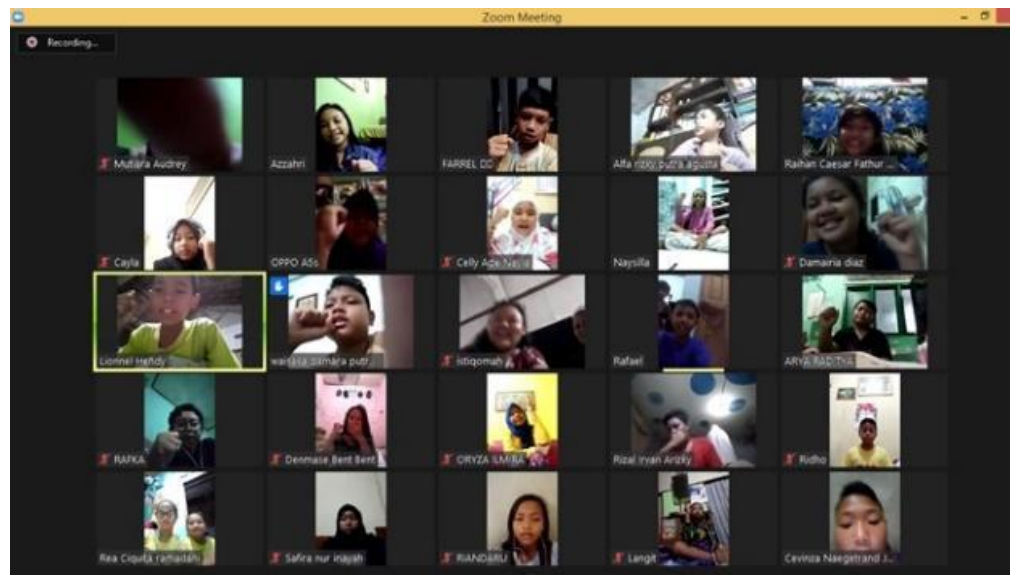

Figure 3: Implementation of class 6 zoom meeting

(5) In addition, researchers also made science learning videos with simple electrical circuit material by using the AZ Screen Recorder application. By utilizing this application in addition to making learning videos, researchers also combine powerpoint slides in the video. Furthermore, this learning video is uploaded to the researcher's YouTube channel. Students are asked to listen to this learning video through the youtube application.

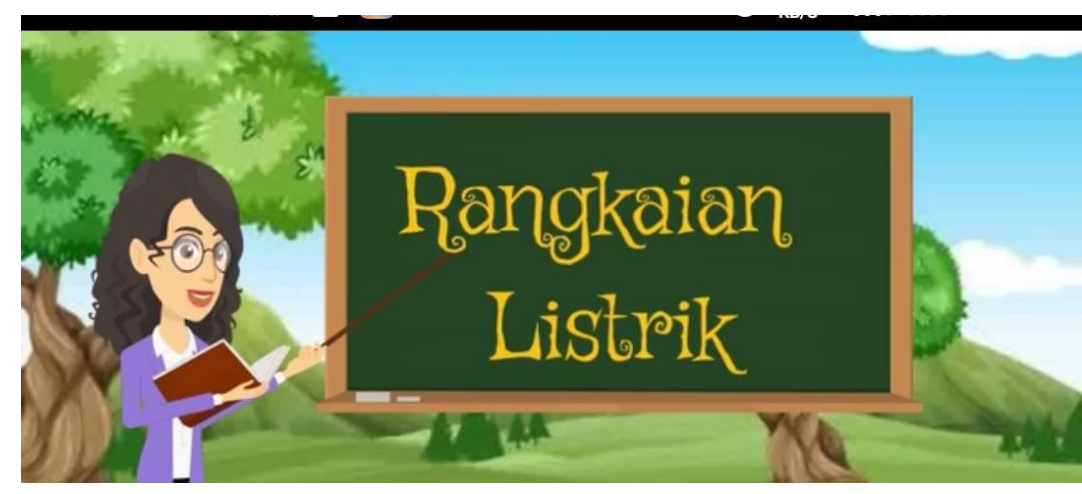

Figure 4: Learning video with electrical circuit material

(1) The results of observations of the stage of making electrical circuit designs in STEAM-oriented online learning

Students are asked to draw a simple electrical circuit design that will be photographed and sent to the WhatsApp (WA) group to be given input by the teacher or by other friends. 


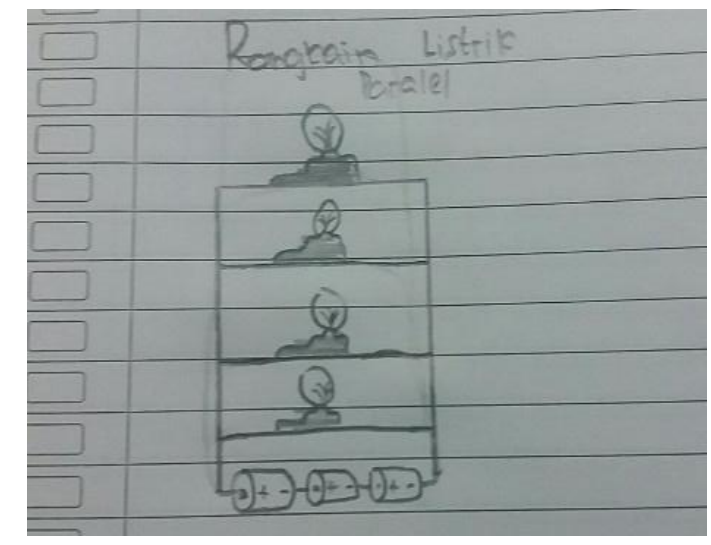

Figure 5: One example of an image designed by students

Students begin to start making designs from designs that have been drawn. At this stage, students work alone with parental guidance at home and if they have difficulty, they can consult with the teacher via WA or telephone. Students present their work by sending videos of the designs that have been made and students doing trials of the designs. the video is sent via wa to the teacher. The teacher appreciates and provides input via WA.

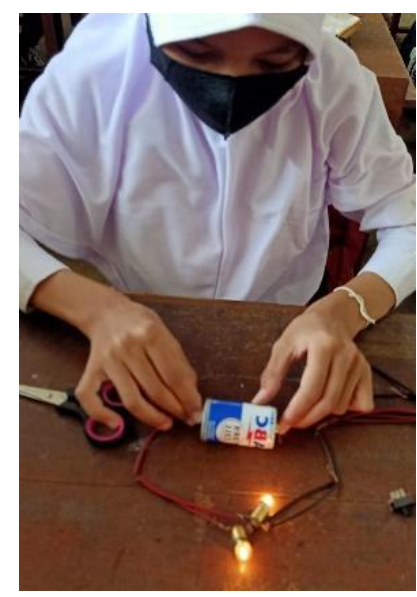

Figure 6: Students design a simple electric circuit

\section{DISCUSSION}

Science learning which is usually done in the classroom, which is identical to practice during the current pandemic, must be done online. As a classroom teacher, you must be extra innovative in designing interesting learning methods that students can do at home. During the learning process from home by utilizing various technological media, parents play a very important role as role models in assisting children's learning. Many parents complain about the implementation of distance learning (PJJ) through online. Because they have to play a double role every day, namely working and accompanying their children to study, especially their children who are still small in elementary school age. Considering that not all parents of students are accustomed to using technology for learning media, such as not being accustomed to operating laptops, gadgets, etc. The teacher's accuracy in determining the learning method or approach has a very important 
role for the success of learning to actualize the learning outcomes that have been formulated. The presentation method was developed by referring to the learning outcomes to be actualized. The learning management that is made is expected to encourage students to be able to find solutions to real-life problems, both individually and in groups, by implementing knowledge and using technological sophistication as a form of concern and contribution in order to improve the quality of the environment responsibly. For this reason, one approach that can be used to bridge this is a STEAM-oriented approach model.

Based on the research findings, the application of STEAM can be supported by various learning methods. STEAM which has an integrative nature provides opportunities for various methods in the world of education to be used to encourage their application in learning. Therefore, educators must be careful in interpreting any existing material. For this reason, a teacher must first create a conceptual framework for the STEAM approach. At the elementary school level, the application of the STEAM approach raises and stimulates students' curiosity through activities that support the process of developing scientific literacy. In addition, activities that apply observation and investigation as one of the most important science skills can also be integrated.(Adriyawati et al., 2020,)(Susanti et al., 2020)(Laforce et al., 2017). The application of STEAM has also been shown to increase creativity.

Online learning by implementing STEAM requires teachers to be able to explore and design interesting and meaningful activities, this encourages teachers to develop into creative teachers. Besides teachers who are required to be creative, students are also indirectly required to be creative individuals to be able to answer challenges and complete tasks in STEAM-oriented online learning (Kim \& Park, 2012)(Nurhikmayati, 2019). The implementation of STEAM raises new challenges in its implementation.

The implementation has a tremendous positive impact, but there are several things that must be considered to implement the STEAM approach in online learning, especially for elementary school students. The application of STEAM requires equipment that must be prepared before implementing STEAM, this requires good cooperation between students, parents and teachers as mentors. However, in online learning, parents inevitably become substitute teachers as long as students study at home. However, not all of them have the capacity and ability needed to implement STEAM. It takes an easy and comprehensive learning media that can help the role of parents in online learning (Munawar et al., 2019).

\section{CONCLUSION}

Previous research related to STEAM was carried out using a face-to-face system so that there was direct interaction between students and teachers. In this study, the application of STEAM was carried out during a pandemic with an online learning system. The findings in this study are expected that many more teachers will apply the STEAM approach in their classrooms. This research has some limitations. The informants selected in this study were students in one class of 27 students, this made the resulting data less diverse and incomplete. Second, the limited ability of both students and parents in operating gadget applications as online learning media. This causes the research to run less smoothly. Further research on the application of STEAM in online learning will be better with more informants and informants who have better mastery of technology so that research can run smoothly. This research has three suggestions. First, during the pandemic, all teachers in Indonesia must innovate in designing learning so that students can still learn meaningfully even with online learning. Second, the role of parents in online learning is very important to accompany their children as a substitute for a teacher at home. The three roles of experts 
in the application of STEAM are needed to create/find learning media that can encourage the implementation of STEAM.

\section{REFERENCES}

Adriyawati, Utomo, E., Rahmawati, Y., \& Mardiah, A. (2020). Steam-project-based learning integration to improve elementary school students' scientific literacy on alternative energy learning. Universal Journal of Educational Research, 8(5), 1863-1873. https://doi.org/10.13189/ujer.2020.080523

Bahri, S., \& Budiyono, F. (2020). Pembelajaran Daring Pada Masa Covid-19 di Kecamatan Kalianget. September, 62-66.

Billiark, K., Hubelbank, J., Oliva, T., \& Camesano, T. (2014). Teaching STEM by design. Advances in Engineering Education, 4(1), 1-21.

Busa, Y., Agusriandi, A., Elihami, E., \& Mutmainnah, M. (2020). Facing Covid-19 in Indonesia: Variations of Learning Media and Online Teaching Learning Through You Tube and Zoom Application. Journal of Critical Reviews, 7(19), 7427-7432.

Daheri, M., Juliana, J., Deriwanto, D., \& Amda, A. D. (2020). Efektifitas WhatsApp sebagai Media Belajar Daring. Jurnal Basicedu, 4(4), 775-783. https://doi.org/10.31004/basicedu.v4i4.445

Daugherty, M. K., Carter, V., \& Swagerty, L. (2014). Elementary STEM Education: The Future for Technology and Engineering Education? Journal of STEM Teacher Education, 49(1). https://doi.org/10.30707/jste49.1daugherty

Farwati, R., Permanasari, A., Firman, H., \& Suhery, T. (2017). Integrasi Problem Based Learning dalam STEM education berorientasi pada aktualisasi literasi lingkungan dan kreativitas. Prosiding Seminar Nasional Pendidikan IPA, 198-206.

Iolanessa, L., Kaniawati, I., \& Nugraha, M. G. (2020). Pengaruh Model Problem Based Learning ( Pbl) Menggunakan Pendekatan Stem Dalam Meningkatkan Keterampilan Pemecahan Masalah Siswa Smp. Wahana Pendidikan Fisika, 5(1), 113-117.

Kemdikbud RI. (2020). Panduan Pembelajaran Jarak Jauh. Kementrian Pendidikan Dan Kebudayaan, 021, 28. https://bersamahadapikorona.kemdikbud.go.id/panduanpembelajaran-jarak-jauh/

Khaira, N. (2018). Pengaruh Pembelajaran STEM Terhadap Peserta Didik pada Pembelajaran IPA. Seminar Nasional MIPA IV, 233-237.

Kim, Y., \& Park, N. (2012). The effect of STEAM education on elementary school Student's Creativity Improvement * Mechanical Mechanism of Rube Goldberg Machine Contest. Computer Applications for Security, Control and System Engineering, 115121.

Kumar, D. D. (2016). Analysis of an Interactive Technology Supported Problem-Based Learning STEM Project Using Selected Learning Sciences Interest Areas (SLSIA). International Journal of Education in Mathematics, Science and Technology, 5(1), 53. https://doi.org/10.18404/ijemst.69590

Laforce, M., Noble, E., \& Blackwell, C. (2017). Problem-based learning (PBL) and student interest in STEM careers: The roles of motivation and ability beliefs. Education Sciences, 7(4). https://doi.org/10.3390/educsci7040092

Melati, L. T., Warsono, \& Toto. (2019). Pengaruh model problem based learning berbasis STEM terhadap penguasaan konsep dan kemampuan berpikir kritis siswa. Bioed: 
Jurnal Pendidikan Biologi, 7(2).

Miles, M. B. (1994). Qualitatif Data Analysis (3rd ed.). SAGE Publications.

Muhamad, S. V. (2021). Pandemi Covid-19 sebagai Persoalan Serius Banyak Negara di Dunia.

Munawar, M., Roshayanti, F., \& Sugiyanti, S. (2019). IMPLEMENTATION OF STEAM (Science Technology Engineering Art Mathematics) - BASED EARLY CHILDHOOD EDUCATION LEARNING IN SEMARANG CITY. CERIA (Cerdas Energik Responsif Inovatif Adaptif), 2(5), 276. https://doi.org/10.22460/ceria.v2i5.p276-285

Nurhikmayati, I. (2019). Implementasi Steam Dalam. Didactical Mathematics, 1(2), 41-50.

Peserta, C., \& Smp, D. (2016). Implementasi Model Susan Loucks-Horsley Terhadap Communication and Collaboration Peserta Didik Smp. Unnes Science Education Journal, 5(1), 1079-1084. https://doi.org/10.15294/usej.v5i1.9565

Purnamasari, I., Handayania, S. S. D., Formen, A., Pd, M., \& Da, P. (2020). Stimulasi Keterampilan HOTs dalam PAUD Melalui Pembelajaran STEAM. 2008.

Sari, R.P., Tusyantari, N.B., \& Suswandari, M. (2021). DAMPAK PEMBELAJARAN DARING BAGI SISWA SEKOLAH DASAR SELAMA SELAMA COVID-19 Universitas Veteran Bangun Nusantara, Sukoharjo. December 2020. https://doi.org/10.37478/jpm.v2i1.732

Susanti, D., Prasetyo, Z. K., \& Retnawati, H. (2020). Analysis of elementary school teachers ' perspectives on STEM implementation. Jurnal Prima Edukasia, 8(1), 40-50. 